\title{
ILL HEALTH AND DISCRIMINATION: THE DOUBLE JEOPARDY FOR YOUTH IN PUNITIVE JUSTICE SYSTEMS
}

\author{
Bernard Schissel
}

\begin{abstract}
The author argues that despite the rhetoric of Canada's youth justice system framework, there is a striking lack of funding for, or commitment to, alternatives to formal justice when dealing with marginalized young people. One consequence of this is an epidemic of ill health, both physical and emotional, among at-risk youth. It is this reality, not criminality, that is the defining characteristic of this vulnerable population. To underline this point, the author presents his research on marginalized Aboriginal youth, and notes that the public perception of young people in conflict with the legal system is defined by fear and hostility rather than sympathy. He also discusses examples of microcommunities that understand the epidemic of ill health plaguing marginalized youth and that provide an antidote to the condemnation of children and youth in the larger society. He notes that for children and youth, involvement with the law is a profound individual and collective health risk and argues against conservative law and order politics. He emphasizes the importance of research driven intervention, crime prevention, and alternatives to the criminal justice system.
\end{abstract}

The dilemma for marginalized youth in conflict with the law is clear. They face a high likelihood of being treated rather harshly with respect to conviction and sentencing and they are characterized by relatively poor levels of physical and emotional health. The reasons for these phenomena have been debated over and over, but the conclusions, at least from good social policy work, suggest the following: (a) Relative privation dictates a high risk for conviction and incarceration; (b) despite the legal/human rights and social welfare mandates of the previous Young Offenders Act and the recent Youth Criminal Justice Act, many young offenders lack access to adequate legal resources and access to adequate health care; (c) most younger offenders, because they live on the margins of society and because of their age, lack political power; and (d) discrimination, either by omission or commission, exists in the justice system and dictates especially harsh treatment for Aboriginal youth and youth from relatively poor families and communities (Schissel, 2006; Bell, 2002a). Despite the rhetoric of Canada's youth justice system framework, there is a striking lack of funding for, or commitment to, alternatives to formal justice. In many ways, our inability to improve the lives of young people in trouble with the law, especially those who are marginalized, is fuelled by our antipathy to young people in general (Côté \& Allahar, 2006; Giroux, 2003a, 2003b). The result of our indifference to the real needs of young people at risk is the focus of this paper.

The manifestation of this indifference is what I describe as an epidemic of ill health among at-risk youth. Ill health, not criminality, is the defining characteristic of the young. Based on research on marginalized youth that I have conducted over several years, I demonstrate that for youth involved in the legal system, poor health provides a double jeopardy in already marginalized lives. As we will see, however, the public's general perception of youth, especially youth in trouble with the law, is certainly not characterized by sympathy. In the end, I provide 
examples of micro-communities that understand the epidemic of ill health amongst marginalized youth and provide an antidote to the condemnation of children and youth in the larger society. These micro-communities attend to the needs of high-risk youth by creating contexts devoted primarily to the improvement of physical and emotional health.

\section{The Condemnation of Age and Race}

There is a rather common attitude amongst the Canadian public that young people are more disrespectful now than in the past, and that they are, in the end, more dangerous. The blame for this "adolescent misbehaviour epidemic" is placed on various sources including the family, but most vigorously, on the justice system. The majority of Canadians feel that the youth justice system is too lenient and that youth are "getting away with murder". The associated perception is that if the youth justice system would simply be made tougher, youth would stop misbehaving. Politicians and other lawmakers are very sensitive to public opinion polls and often act to satisfy the fears of the public. In the case of young offenders, the Canadian government's typical reaction has been to tinker with the law in hopes of responding to the fears and demands of the voting public. Canada's Youth Criminal Justice Act is, in many ways, a typical legal reform response that has contradictory philosophies: one of genuine concern that many young offenders need alternatives to incarceration for their own welfare - that they need to be reintegrated into the community - and one of overriding concern that society needs to be protected from young people who break the law. For example, the act has provisions for community-based alternatives to the justice system but at the same time, it is devoted to a reduction in the age at which a child can be considered a young offender and a reduction in the age at which a young offender can be transferred to adult court, and ultimately, adult prison. Both provisions are based on the concept of "societal protection" despite research that suggests that youth in adult prisons face incredibly high rates of physical and emotional jeopardy (Schiraldi \& Zeidenburg, 1997).

I maintain that children and youth represent now, maybe more than ever, political and economic scapegoats. At a time when societies are becoming more sensitive to and cognizant of the rights of a diversity of citizens, children and youth are left out of the human rights debates. The reality is that children and youth are no more criminal or dangerous than in the past and this contradicts the public perception that they are. Traditional sociological and criminological approaches to crime and punishment have played a significant role in fostering a generalized belief that "evil" children and youth are "out there", that they are either born bad or made bad by bad cultures in which they live. The public policy and academic research that has a "bad kids" focus has centred on the individual and his or her socio-cultural characteristics, while largely ignoring the possibility that attacking children and youth is a political act with political and economic motivations. More critical approaches to crime and justice contend, on the other hand, that punishing children and youth through a rigid justice system benefits those in positions of power. In the end, the definition of youth crime and the extent to which we deal with children and youth deviance is largely a reflection of how important children and youth are to the Canadian political economy.

It is important to state here that the political/legal attack on children and youth in Canada is highly racialized. Currently, the Province of Saskatchewan locks up more young offenders per capita than all other jurisdictions in the developed world. The largest proportion of these young 
offenders is of Aboriginal ancestry, a proportion much larger than the proportion of Aboriginal children and youth in the population at large. My research reveals several relevant demographic phenomena: About 45\% of youths with young offender dossiers in Saskatchewan Social Services are of Aboriginal ancestry; $88 \%$ of the youth in conflict with the law in urban outreach programs in Prince Albert and Edmonton are of Aboriginal ancestry; and, 65\% of the youth in closed custody in Saskatoon and 41\% in North Dakota are of Aboriginal ancestry. The proportion of Aboriginal youth in the Province of Saskatchewan in 2001 is 15.1\% of all youth; in the next 15 years the Aboriginal youth population is expected to be $26 \%$ of the entire youth population. These statistics illustrate a marked overrepresentation of Aboriginal youth in the young offenders system, an even more exaggerated overrepresentation in closed custody, and, at the current rates of apprehension, a potential for an even larger young offender population in the next 15 years.

In addition to the excessive incarceration of Aboriginal youth, the discourse of youth crime is often fraught with words and phrases that implicate Aboriginal youth (Schissel, 2006; Saskatchewan Justice, 2004) or African-Canadian youth (Henry, Tator, Mattis, \& Rees, 2000) or other racialized categories of young people as particularly troubled or dangerous. As mentioned previously, the central focus of this paper is that youth in trouble with the law are characterized primarily by jeopardized health. Ironically, as we will see, the discourse that condemns youth is largely about health and medicine; medical discourse is part of the condemnatory language that is used to isolate race (and class and gender). The following story illustrates how such condemnation occurs, especially in the context of race.

\section{Scapegoating Youth: A Story of Race and “Justice”}

In October of 1998, Serena Nicotine, a First Nations young offender residing in a halfway house in Prince Albert, Saskatchewan, in concert with another young offender, murdered Helen Montgomery, the owner of the halfway house. The murder was unprovoked and the two young women showed little apparent remorse for their crime. The subsequent drama that played out in public discourse, in large part within the local and national press, revealed an oft-told story of young people who have no respect for law and order, ultimately no respect for anyone but themselves, and who are born into circumstances whereby they were neglected or damaged by dysfunctional parents. In fact, headlines such as Blood and Betrayal: Fetal Alcohol Syndrome: Serena Nicotine - Sins of the Mother (Saskatoon StarPhoenix, November 27, 1999, p. E1) were commonplace as the press tried to frame the story of the offenders within a context of race, gender and single-motherhood, and trans-generational criminality.

These popular culture versions of youth and cultural nihilism were interposed with accounts of well-meaning people who are the unwitting victims of killer kids. And, in the course of the legal intrigue that followed the murder, the community launched a petition, in concert with conservative provincial and federal politicians, to lobby the federal government to increase the severity of penalties under the Young Offenders Act. The law, especially the police, supported the community lobby and made public declarations that citizens must be protected from youth violence. Ultimately, the province shouldered the blame for not building enough open and closed custody facilities and for not building enough jails. 
The Crown prosecutor, in concert with local politicians and community leaders, was successful in having Nicotine's case moved to adult court. Despite the initial 8-year sentence in adult prison, the lobby to toughen up the Young Offenders Act became intensified, and both the Crown and politicians were adamant that the law was too lenient in dealing with young offenders. And, as we now know, that law has been reformed with intensified provisions for dealing with young offenders deemed to be a danger to the society. Both the Crown and politicians recommended harsher punishment as an effective deterrent and a moral response. In the years since Ms. Nicotine's original incarceration, she has been a perpetrator of a hostage incident and several other violent confrontations in prison.

What is interesting about the Nicotine case, however, is that the social justice debates about the history of the offender as a victim at a very young age rarely occurred. When such commentary did occur, it was relegated to the last few lines of news reports. Even the legal debates ignored the facts that both girls had been violently victimized as children. Nicotine had witnessed the violent death of her father. Both girls were "systems kids" who had been in and out of the justice and social welfare system for most of their formative years. These are very important justice details because they help us understand and should help us deal with highly disadvantaged children and youth. Amazingly, the Crown prosecutor, as the voice of the law, never engaged in this important discourse, even when social justice organizations raised important issues. The discourse that played out in the press instead focused largely on young people who have no respect for law and order.

From a socio-legal perspective, this case is instructive because it helps us understand how the law, in concert with public opinion, has exceptional ideological power. When the law's voice is essentially devoid of social justice, especially in high profile cases such as Nicotine's, and when the law stands for alarmist politics in violation of the social welfare tenets of the youth justice system, its primary function might conceivably be to legitimate and/or appease orthodox political lobbies. In the Nicotine case and others, the law is unable to dispense social justice. It unavoidably renders opinions that condemn those who are already condemned, especially young people like Nicotine who are disconnected from family and community, who are Aboriginal, who are young and defiant, and who have been damaged at a young age. I cannot remember a time when the law officially went against public opinion and declared that young offenders are victims before anything else. In other words, the de facto mandate of the law is not to provide justice but to account for injustice. Simply put, the law has less to do with social justice, differential oppression, social inequality, prejudice, or discrimination and more to do with collective condemnation of those who stand outside what we deem to be conventional society. More disturbingly, the law creates racialized, gendered, and classed versions of bad citizens. In the case of Nicotine, her Aboriginality, her youth, her upbringing, her gender, her poverty, and her socio-cultural background were traits that helped to damage her character in the eyes of the world and relegate her to the ranks of the expendable. There is a very good chance that she will be declared a dangerous offender and will remain in jail the rest of her life, potentially 70 or 80 more years.

As we observe and analyze cases such as these, it is evident that the law's purpose to provide justice and to protect the rights of young people is suspect. This contention is no more evident than when we observe the relative physical and emotional condition of children and 
youth in custody or who have been deemed "at risk". The following analytical results describe the health crisis in which young offenders and kids on the street find themselves.

\section{Throwaway Youth: Life on the Streets}

One of the main arguments in my work is that, for youth, poverty simultaneously dictates health risk with criminal justice involvement. The following data show how living on the margins of society significantly endangers the health of society's most marginalized youth. In 1999, Kari Fedec and I (Schissel \& Fedec, 1999) conducted a study of street youth by examining the files of youth offenders with respect to the Young Offenders Act. A subset of these data was based on young offenders who had been charged for being involved in the sex trade. The youth in this study were largely street youth in the City of Saskatoon and constituted a cross-section of youths who had been convicted under the Young Offenders Act and who were involved in the sex trade. The following table compares the health risks for street youths involved in the sex trade compared to young offenders who were not. As most of the literature on youth and street life suggests, prostitution is a response to economic need, and the youth involved represent the most marginalized adolescents in society. 
Table 1: The Health of Young Offenders by Race and Involvement in the Sex Trade

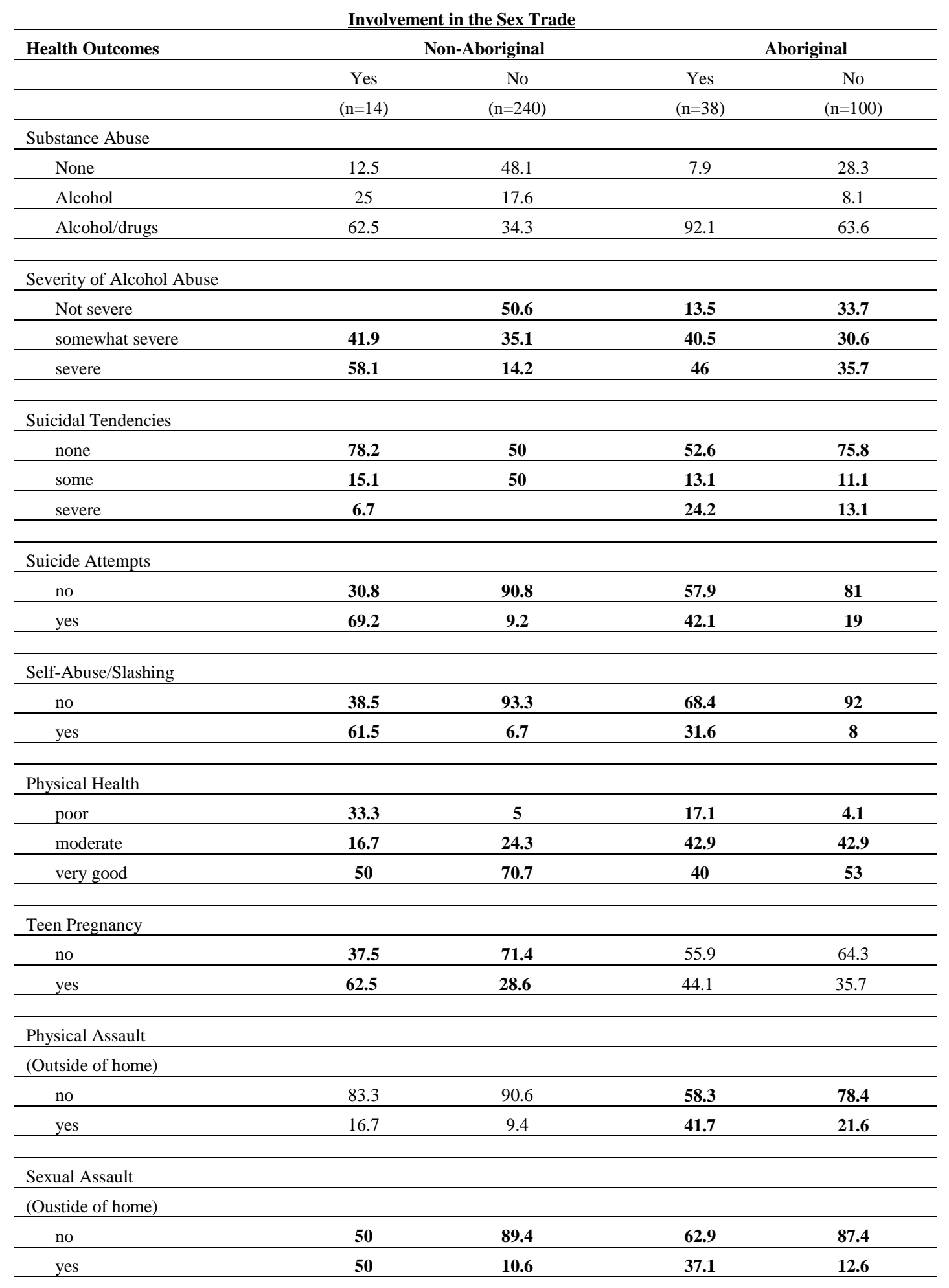

Note: Significant chi-square .05 in bold face 
The two most important phenomena in this table are the astonishing increase in health risk for youth involved in the sex trade and the absolute levels of health risk for both groups of youth. The table shows clearly that for both non-Aboriginal and Aboriginal young offenders, being involved in the sex trade results in relatively high rates of health risk. Specifically, substance and alcohol abuse pose immediate problems for all youth, but again, especially for youth in the sex trade. For example, 58.1\% of non-Aboriginal youth involved in the sex trade have severe alcohol problems, as do $46 \%$ of Aboriginal youth; these percentages are considerably higher than those for youth not involved in the sex trade. For youth who are living dangerous and unpleasant lives, substance abuse may be the only reasonable forum for normalizing an otherwise intolerable life situation.

The jeopardy for youth on the street is further evidenced by indicators of self-injury. Specifically, $69.2 \%$ of non-Aboriginal youth involved in the sex trade have attempted suicide as have $42.1 \%$ of Aboriginal youth. Similar results appear for suicidal tendencies; $24.2 \%$ of Aboriginal youth and $6.7 \%$ of non-Aboriginal youth involved in the sex trade have severe suicidal tendencies. Finally, while a small percentage of all youth in the study has engaged in slashing, $61.5 \%$ of the non-Aboriginal youth in the sex trade have slashed themselves as have 42.1\% of Aboriginal youth; the percentages for those not in the sex trade are appreciably smaller but still distressingly present. The phenomenon of slashing is important in understanding the trauma of marginality. The research on slashing has argued that it is a form of emotion-masking behaviour typical of people who are in extremely traumatic life situations, exemplified by the high rates of slashing amongst women prisoners (Shaw, 2000; Faith, 1993). The alarmingly high rates of slashing amongst youth prostitutes reveal quite clearly the extreme psychic trauma under which they live. That a considerable number of youths in this study engage in slashing is indicative of the marginal and traumatic nature of life for many young offenders.

In terms of overall physical health, it is clear that not all youth in our society are healthy but youth in the sex trade suffer considerably more poor health than those who are not. For example, only $50 \%$ of non-Aboriginal youth in the sex trade and only $40 \%$ of their Aboriginal counterparts have very good health. Furthermore, pregnancy poses a health risk for female street youth and also places their unborn children at risk. Pregnancy is also an indicator of high-risk sexual activity so this subgroup of street youth is obviously engaging in unprotected sex: "Unprotected sex is a valuable commodity in the sex trade and the highest profits are obtained from the prostitution of young girls who are willing to engage in unprotected sex" (Schissel \& Fedec, 1999, p. 38). Female street youth not only run the risk of pregnancy, they obviously are exposed to sexually transmitted diseases including HIV/AIDS and carcinogenic STDs. Pregnancy rates are alarmingly high for non-Aboriginal youth in the sex trade, $62.5 \%$ of whom have been pregnant.

Lastly, it is important to consider the risk of victimization as an ever-present health risk for youth. Clearly, in terms of physical assault, Aboriginal youth are highly vulnerable to physical assault; for example, $41.7 \%$ involved in the sex trade have been physically assaulted to the extent that they have required medical care. The findings for sexual assault are similarly alarming. For youth involved in the sex trade, $50 \%$ of non-Aboriginal youth and $37.1 \%$ of Aboriginal youth have been sexually assaulted. 
It is clear from these data that young offenders, as marginalized youth, are exposed to severe medical trauma. Their health risks include substance abuse, self-injury, high-risk sexuality, and extreme levels of victimization. Importantly, for the most marginal person in the society, the inner city street kid who sells her or his body to survive, the medical jeopardy is startling.

\section{Youth Declared as “At Risk”}

The data for this section are based on self-administered questionnaires and face-to-face interviews with young people who had been or were in trouble with the law in Saskatchewan, Alberta, and North Dakota. The 2002-2003 survey was conducted on 163 youth who were either in closed custody, street programs for youth in open custody, and street programs for noncustodial youth deemed at risk and focused on issues of socio-economic background, familial experiences, and experiences with the legal system. The research was intended to understand the lives of youths who are highly marginalized and disaffiliated and who end up in the justice system by investigating the dilemma that youth face, especially as they come to confront youth justice systems or agencies of social assistance. It explored, in part, the racialized nature of youth justice in western Canada and in one northern U.S. state.

For the analysis, I compare male and female youth of Aboriginal and non-Aboriginal ancestry in an attempt to understand the gendered and racialized nature of the mechanisms through which youth who live on the margins of the society come to be identified and defined as criminal or "at risk". By correlating dimensions of health and criminal involvement, I show that the characteristics that describe youth in conflict with the law are, for the most part, not criminal characteristics but characteristics of ill health, both individual and communal. Table 2 illustrates the extent of poor condition for both male and female and Aboriginal and non-Aboriginal youth. The intention in presenting this table is to show the absolute levels of health outcomes and legal involvement and the associations between these variables and race and gender. 
Table 2: Health Outcomes and Legal Involvement for Aboriginal and Non-Aboriginal youth and for male and female youth

\begin{tabular}{|c|c|c|c|c|c|c|}
\hline & & $\begin{array}{l}\text { Non- } \\
\text { Aboriginal }\end{array}$ & Aboriginal & Female & Male & Total \\
\hline \multicolumn{7}{|l|}{ Health Outcomes } \\
\hline Physical Health & Below average & $7.70 \%$ & $11.70 \%$ & $12.30 \%$ & $9.40 \%$ & $10.40 \%$ \\
\hline \multirow[t]{3}{*}{ Rating } & Average & $63.50 \%$ & $69.40 \%$ & $75.40 \%$ & $63.20 \%$ & $67.50 \%$ \\
\hline & Above average & $28.80 \%$ & $18.90 \%$ & $12.30 \%$ & $27.40 \%$ & $22.10 \%$ \\
\hline & & $\mathrm{N}=52$ & $\mathrm{~N}=111$ & $\mathrm{~N}=57$ & $\mathrm{~N}=106$ & \\
\hline \multirow[t]{4}{*}{ Times depressed } & Rarely & $42.30 \%$ & $48.60 \%$ & $26.30 \%$ & $57.50 \%$ & $46.60 \%$ \\
\hline & Sometimes & $17.30 \%$ & $27 \%$ & $33.30 \%$ & $18.90 \%$ & $23.90 \%$ \\
\hline & Often & $40.40 \%$ & $24.30 \%$ & $40.40 \%$ & $23.60 \%$ & $29.40 \%$ \\
\hline & & $\mathrm{N}=52$ & $\mathrm{~N}=111$ & $\mathrm{~N}=55$ & $\mathrm{~N}=106$ & \\
\hline \multirow[t]{3}{*}{ Attempted Suicide } & Yes & $32.70 \%$ & $29.10 \%$ & $42.10 \%$ & $23.80 \%$ & $30.20 \%$ \\
\hline & No & $67.30 \%$ & $70.90 \%$ & $57.90 \%$ & $76.20 \%$ & $69.80 \%$ \\
\hline & & $\mathrm{N}=52$ & $\mathrm{~N}=110$ & $\mathrm{~N}=57$ & $\mathrm{~N}=105$ & \\
\hline \multirow[t]{4}{*}{ Self-Injury } & Never & $65.40 \%$ & $73.60 \%$ & $64.90 \%$ & $74.30 \%$ & $71 \%$ \\
\hline & Sometimes & $32.70 \%$ & $21.80 \%$ & $29.80 \%$ & $22.90 \%$ & $25.30 \%$ \\
\hline & Often & $1.90 \%$ & $4.50 \%$ & $5.30 \%$ & $2.90 \%$ & $3.70 \%$ \\
\hline & & $\mathrm{N}=52$ & $\mathrm{~N}=110$ & $\mathrm{~N}=57$ & $\mathrm{~N}=105$ & \\
\hline \multirow[t]{3}{*}{$\begin{array}{l}\text { Victimized at } \\
\text { school }\end{array}$} & Yes & $19.40 \%$ & $20.80 \%$ & $10 \%$ & $25.90 \%$ & $20.80 \%$ \\
\hline & No & $80.60 \%$ & $79.20 \%$ & $90 \%$ & $74.10 \%$ & $79.80 \%$ \\
\hline & & $\mathrm{N}=31$ & $\mathrm{~N}=53$ & $\mathrm{~N}=30$ & $\mathrm{~N}=54$ & \\
\hline \multirow[t]{3}{*}{ Attacked } & Yes & $51.60 \%$ & $60.70 \%$ & $63.60 \%$ & $53.70 \%$ & $57.50 \%$ \\
\hline & No & $48.40 \%$ & $39.30 \%$ & $36.40 \%$ & $46.30 \%$ & $42.50 \%$ \\
\hline & & $\mathrm{N}=31$ & $\mathrm{~N}=56$ & $\mathrm{~N}=33$ & $\mathrm{~N}=54$ & \\
\hline Sexually assaulted & Yes & $22 \%$ & $23.40 \%$ & $45.60 \%$ & $10.60 \%$ & $23 \%$ \\
\hline \multirow[t]{2}{*}{ outside of home } & No & $78 \%$ & $76.60 \%$ & $54.40 \%$ & $89.40 \%$ & $77 \%$ \\
\hline & & $\mathrm{N}=50$ & $\mathrm{~N}=111$ & $\mathrm{~N}=57$ & $\mathrm{~N}=104$ & \\
\hline Physically assaulted & Yes & $48 \%$ & $50.90 \%$ & $47.30 \%$ & $51.50 \%$ & $50 \%$ \\
\hline \multirow[t]{2}{*}{ by a stranger } & No & $52 \%$ & $49.10 \%$ & $52.70 \%$ & $48.50 \%$ & $50 \%$ \\
\hline & & $\mathrm{N}=50$ & $\mathrm{~N}=108$ & $\mathrm{~N}=55$ & $\mathrm{~N}=103$ & \\
\hline \multicolumn{7}{|l|}{ Legal Involvement } \\
\hline Age category & under 12 yrs. & $46 \%$ & $27.40 \%$ & $13.90 \%$ & $43.70 \%$ & $35 \%$ \\
\hline \multirow[t]{3}{*}{ of first offence } & 12 - 14 yrs. & $40 \%$ & $50.70 \%$ & $58.30 \%$ & $41.40 \%$ & $46.30 \%$ \\
\hline & 15 - 18 yrs. & $14 \%$ & $21.90 \%$ & $27.80 \%$ & $14.90 \%$ & $18.70 \%$ \\
\hline & & $\mathrm{N}=50$ & $\mathrm{~N}=73$ & $\mathrm{~N}=36$ & $\mathrm{~N}=87$ & \\
\hline Number of & Never & $41.20 \%$ & $74.70 \%$ & $84.40 \%$ & $52.60 \%$ & $62.70 \%$ \\
\hline \multirow[t]{3}{*}{ convictions } & Once or twice & $35.30 \%$ & $16.50 \%$ & $6.70 \%$ & $30.90 \%$ & $23.20 \%$ \\
\hline & More than two & $23.50 \%$ & $8.80 \%$ & $8.90 \%$ & $16.50 \%$ & $14.10 \%$ \\
\hline & & $\mathrm{N}=51$ & $\mathrm{~N}=91$ & $\mathrm{~N}=45$ & $\mathrm{~N}=97$ & \\
\hline Ever moved to & Yes & $23.10 \%$ & $11.20 \%$ & $7.30 \%$ & $19.20 \%$ & $15.10 \%$ \\
\hline \multirow[t]{2}{*}{ adult court } & No & $76.90 \%$ & $88.80 \%$ & $92.70 \%$ & $80.80 \%$ & $84.90 \%$ \\
\hline & & $\mathrm{N}=52$ & $\mathrm{~N}=107$ & $\mathrm{~N}=55$ & $\mathrm{~N}=104$ & \\
\hline Risk of & Low & $48.10 \%$ & $58 \%$ & $62.70 \%$ & $50.50 \%$ & $54.60 \%$ \\
\hline \multirow[t]{4}{*}{ re-offending } & Moderate & $19.20 \%$ & $24 \%$ & $23.50 \%$ & $21.80 \%$ & $22.40 \%$ \\
\hline & High & $15.40 \%$ & $14 \%$ & $13.70 \%$ & $14.90 \%$ & $14.50 \%$ \\
\hline & Extremely high & $17.30 \%$ & $4 \%$ & & $12.90 \%$ & $8.60 \%$ \\
\hline & & $\mathrm{N}=52$ & $\mathrm{~N}=100$ & $\mathrm{~N}=51$ & $\mathrm{~N}=101$ & \\
\hline \multirow[t]{4}{*}{ Police contact } & Never & $22.40 \%$ & $31.10 \%$ & $37.80 \%$ & $23.40 \%$ & $28.10 \%$ \\
\hline & 1 to 4 times & $49 \%$ & $52.20 \%$ & $53.30 \%$ & $50 \%$ & $51.50 \%$ \\
\hline & 5 or more times & $28.60 \%$ & $16.70 \%$ & $8.90 \%$ & $26.60 \%$ & $20.90 \%$ \\
\hline & & $\mathrm{N}=49$ & $\mathrm{~N}=90$ & $\mathrm{~N}=45$ & $\mathrm{~N}=94$ & \\
\hline
\end{tabular}


Because the data in Table 2 is presented as both descriptive and associational (with race and gender), the significant relationships are presented in boldface. The table is quite complex so I will leave it to the reader to look at the data in detail. I wish, however, to point to some of the more stark findings that frame the arguments in this paper. For example, the attempted suicide, self-injury, and depression outcomes illustrate quite vividly the extent of jeopardy in which these young offenders live: 30\% of the youth have attempted suicide and 29\% have slashed/self-injured; furthermore, over $50 \%$ of the youth are depressed (as per clinical evaluation) at times. Interestingly, for the depression variable, female youth show higher levels of depression compared to their male counterparts, as do non-Aboriginal youth compared to Aboriginal youth. It is interesting to note, here, that these three indicators of health jeopardy do not correspond to the self-assessment of health. In fact, only $10.4 \%$ of all youth indicate that their general health is poor despite the findings regarding suicide, self-injury, and depression. Clearly, the young people in this study overestimate their own levels of health or have fairly low expectations as to what constitutes being healthy.

As we proceed through the table, it becomes clear that the health of the young people in this research is jeopardized by lack of safety and security. This is especially apparent for the experiences of being attacked and assaulted outside the home. For example, 57.5\% of the youth report being attacked violently in their lives, $23 \%$ report being sexually assaulted by a stranger (this experience is significantly greater for female youth than male), and 50\% report being physically assaulted by a stranger. Clearly, the context in which these young people live exposes them to considerable health risk from assault.

The last variables in this table indicate the degree to which the youth in this study reported being involved with the justice system. The two most glaring findings involve the age of first offence and whether they had been moved to adult court. Firstly, 35\% of the youth report being first involved with the law under the age of 12. Secondly, $15.1 \%$ of youth report being moved to adult court, an indication largely of the extent of their involvement with the law and the law's predisposition to deal with young offenders quite harshly.

Although these legal involvement variables are primarily descriptive, I wish to discuss the differences especially between racial categories. It is clear from the significant relationships dealing with race, Aboriginal youth compared to their non-Aboriginal peers are older at first offence, have fewer convictions, are moved to adult court less, have lower risks of reoffending, and have lower police contact. Aboriginal youth, empirically, are less involved in criminal offences than non-Aboriginal youth. The reality, however, is that Aboriginal youth have higher rates of incarceration and longer sentences than do non-Aboriginal youth, despite the fact that non-Aboriginal youth seem to be more involved with the law (Saskatchewan Justice, 2004; Royal Commission on Aboriginal Peoples [RCAP], 1996; Schissel, 1993; Hamilton \& Sinclair, 1991). Clearly, there are inequities across race for youth in the justice system. The public perception is that Aboriginal youths are highly criminogenic because they have high rates of involvement in the justice system. In fact, their involvement in the justice system is not borne out by their criminal involvement, especially in contrast to non-Aboriginal youth.

The question that remains, then, is this: How does it come to pass that a system predicated on principles of justice treats problems of individual and community health as problems of criminality? 


\section{A Story of an At-Risk Society}

The answer to the aforementioned question lies with an understanding of how marginalized people, including children and youth, fit into Canada's political economy. As we will come to see, questions of health, social justice, and the creation and sustainability of healthy communities are subordinated to the demands of industrialization. York (1992) in his book, The Dispossessed, confronts these issues as he links the development of a resource-based economy to the destruction of peoples and communities. He describes how rapid industrialization in Canada and the expropriation of Aboriginal lands and communities in the 1950s and 1960s eroded Aboriginal communities to the point of extinction. Interestingly, he uses an example from Australia to make the point that Aboriginal people are in jeopardy in many industrialized countries. He reveals how the connections between industrial exploitation and industry-based education have made children and youth suffer:

For centuries, the children of Elcho Island were educated by their relatives. Today the Western educational system has intruded, cutting across the responsibilities of the aboriginal adults and placing a barrier between man and boy. . .the aboriginal adolescent is doubly excluded. On the one hand he is blocked from sharing in the benefits of European society by educational deficiencies and by the fear of breaking step; on the other, he is ambivalent about many of the old ways. Some he has forgotten altogether . . . Gasoline sniffing is a result of the disorientation of the Murngin adolescents . . . Adolescents reflect the conflicts of a people. (York, 1992, p. 17)

In this simple, poignant example, we see how cultural invasion through education has a direct and profound effect on the welfare of children and youth. The problem of gas sniffing is epidemic in many exploited communities in North America and Australia, and the question remains why gasoline sniffing has taken over the lives of some young people. Most importantly, from a critical criminological perspective, we need to understand how the trauma that marginalized children and youth and their families experience - and their resulting conduct gets translated into definitions of criminal deviance or pathological culture rather than jeopardized health. For at the end of the day, in Canada, Aboriginal children and youth have a greater likelihood of being convicted for criminal violations than do their non-Aboriginal counterparts. Importantly, courts rarely understand or take into account issues of historical oppression or cultural devastation in their day-to-day dealings with Aboriginal young offenders. And, in many cases, the criminality of Canada's youth is largely tied to substance use and abuse, issues that in any other context would be considered as health issues.

A Canadian example presents a heart-rending reminder that the structural conditions of a society can have devastating effects on children and youth. On January 26, 1993, six Innu youth in Davis Inlet, Labrador, tried to commit suicide together by sniffing gasoline. Their attempt at collective death was thwarted by an addictions counsellor who heard the youth declare that they wanted to die. Subsequently, 14 youth from this small community were airlifted south for medical treatment, but the legacy of colonialization and government neglect remained, in that $95 \%$ of the adult population was addicted to alcohol, $10 \%$ of the children and youth were chronic gasoline sniffers, and $25 \%$ of the adults had attempted suicide. Seven years later, the trauma for Davis Inlet had grown. In November of 2000, 20 Innu children were, again, airlifted 
to the Goose Bay treatment centre as an interim reaction to another epidemic of gas sniffing among the children. Of the 169 children (ages 10-19) living in Davis Inlet at the end of 2000, 154 have attempted gas sniffing and 70 of them are chronic sniffers. The socio-economic reality for Davis Inlet, like many other northern Aboriginal communities in Canada, is one of historical resource exploitation and/or community relocation, and the imposition of Euro-Canadian education.

\section{Healthy Contexts}

How we respond to issues of risk and marginality for children and youth indicates the quality of social justice in our society. Unfortunately, to date, Canada's record appears to be mostly a record of condemnation and not of concern (Schissel, 2006; Green \& Healy, 2003; Bell, 2002b; Mallea, 1999). There are, however, pockets of caring where change does occur, if only at a rather microscopic level. Importantly, these rather rare examples are important because they illustrate what just social policy can accomplish, especially policy that is based on healing (and health) and not on punishment.

In their struggle to dispense real justice, the courts are faced with several problems in regard to social justice and youth. Most importantly, the courts are overburdened with young offender cases and closed custody institutions have been historically filled to overflowing, although since the inception of the Youth Criminal Justice Act, the youth closed custody population has decreased. Secondly, even if the courts were not oversubscribed, theirs is not an activist mandate; they are mostly unable or unwilling to address issues of poor health and social inequality (Green \& Healy, 2003). Thirdly, the majority of youth plead guilty and are, therefore, merely processed in and out of the system. This fact is borne out, in part, by the reality that youth are not always represented by counsel and when they are represented by legal aid or court-appointed counsel, the legal time given to them is minimal and they rarely have their cases contested (Schissel, 2002). Quite clearly, given these concerns, effective alternatives to "incarceration justice" are needed and, most importantly, these alternatives need to be connected to health.

Interestingly, a health-oriented, holistic approach to youth justice does not preclude the role of the justice system. In fact, it asks that policing and jurisprudence expand to incorporate issues of social justice, social and personal health, and preventive social reform. In short, alternative schools and programs for healing in conventional schools, in concert with the legal system, become places where high-risk children and youth learn not only educational and occupational skills (and meaningful apprenticeships) but also the skills for well-rounded citizenship and individual development.

I have explored several examples of how this might work. The School Officer Liaison Program in the City of Regina has police officers, as mentors and advisors, spend time in schools with students. The program bridges the gulf of mistrust between youth and the law and is a typical example of how law and education blend. Another example from the City of Saskatoon illustrates how law and education combine to create a context of trust that goes a long way toward preventing crime. Several years ago, the city implemented its first community police station in the heart of the inner city, close to several elementary schools. The police officers in this detachment took it upon themselves to visit the schools on a daily basis to 
interact with the students either through sports or just plain talk. The principals and staff of one of these schools indicated how important this practice was to the lives of the students and how effective the police were in creating a safe and secure environment for the students. In effect, the staff was saying that law enforcement practised in this manner is more effective than the typical crime control/“lock-'em-up” mandate of traditional police forces. Unfortunately, due to fiscal pressures, the community station and its programs were cancelled. The ongoing resource problem is exacerbated by the reality that the police are asked to perform a diversity of tasks including militaristic-style policing. Their mandate is unclear.

We need to look, however, no further than the boundaries of Canada for effective and important alternatives to the formal youth justice system. Mediation and alternative measures for young offenders, as originally mandated by the Young Offenders Act and now by the Youth Criminal Justice Act, have been used as alternatives to youth courts. The John Howard Society has for years been involved in programs that stress keeping kids out of custody and giving them opportunities whereby they can make reparation and, at the same time, receive counselling to restore themselves. Healing and Sentencing Circles are common in many Aboriginal communities in Canada and, especially in Northern communities, are replacing the system of circuit court law that tended to "process” people with little concern for cultural and personal considerations.

For centuries, First Nations communities have dealt with anti-social behaviour through a community well-being approach that has melded the best interests of the community with the best interests of the offender. The simple, yet profound basis of this healing philosophy is that it is more appropriate and ultimately safer for the society to bring the offender back into the fold than to punish or remove her or him from the community. When we consider that the typical repeat young offender in Canadian society is one whose past is typified by abuse and punishment, it makes little moral or practical sense to continue this abuse and punishment with legal sanction. Furthermore, from a healing perspective, when someone violates the community or when someone is punished the community suffers collectively. The goal, then, should be to reduce punishment and, as a result, to reduce personal and collective victimization.

Interestingly, within Canada we have examples of success that also occur at the legislative level. The Province of Québec has made a devoted effort to keep young offenders out of the justice system and ultimately out of jail. They have, as a solution, moved for several decades toward community-based programs based on healing and rehabilitation (Green \& Healy, 2003; Hogeveen \& Smandych, 2001). In a very real sense, Québec has pursued a policy that involved diversion from formal law to treatment in the community, in the true spirit of the Young Offenders Act and the Youth Criminal Justice Act. Importantly, their achievements stand out in Canada as a relative success story. For example, in 1999, one in 57 youth who committed an offence in Québec was incarcerated compared to one in 17 in Ontario (Mallea, 1999). The Province of Newfoundland and Labrador in the last few years has made a concerted effort to keep young people out of custody by relying on family, friends, and other devoted community members to take an active role in caring for young offenders (Newfoundland, 2001). Their program has been successful in maintaining one of smallest provincial youth crime rates in Canada. So, the goal of diversion and care appears to be not just an illusion, but rather may have real justice potential when it is constructed within social justice principles. The question remains, however, whether simply diverting young people from the justice system actually translates into policy that is effective in 
reducing young people's criminal involvement (Doob \& Cesaroni, 2004). The following stories show how social justice principles can work at a grassroots level.

\section{Alternative Schools, Health, and Justice: Won Ska Cultural School}

Won Ska Cultural School in Prince Albert, Saskatchewan, exemplifies an alternative education program that provides a context in which troubled youth can heal. Won Ska deals with First Nations street kids and adults who have been in trouble with the law, identified by social services as “at risk". The school began in 1993 in response to a high dropout rate for Aboriginal students in Prince Albert. First Nations and Metis parents, community agency workers, teachers from other schools who had a vision for a new school, and youth created an alternative program for the school.

Won Ska is successful for several reasons. Firstly, for many of the students who have been in trouble with the law, this school is the only place that deals with the fundamental issues that resulted in their legal problems. Secondly, the school mandates that the transition from childhood and adolescence to adulthood is a fundamental priority. The school is administered in a democratic way in which students, essentially, have the final say in their educational development. The teacher as mentor is of profound importance. The mentoring process includes not only training and the transmission of knowledge, but also the creation of a context in which ideas are shared and in which the mentors listen as much as they speak. Most students in this school have missed out on the basic, fundamental rights of young citizens: a concerned and patient audience; a physically and emotionally safe context; a place where what they say is as important as what they learn; a chance to influence their life circumstances; an opportunity to make explanation and reparation; and a chance to see and emulate responsible, caring adults.

The last point, the need for adult role models, is paramount to this new paradigm of healing and learning. It is through interaction with and emulation of caring adults that marginalized youth develop basic life skills which include the ability to perform the day- to-day tasks that facilitate living, to understand what constitutes responsible parenting and responsible intimacy, to overcome the frustration that lands them in trouble, and to learn to trust people in positions of authority. The majority of students in alternative educational programs (students who are from the streets or who are in young offender alternative measures programs), when interviewed expressed an overwhelming fear and distrust of the police and other legal officials and a generalized discomfort in conventional schools. Significantly, many of these students, when asked where they would be without an effective alternative school, immediately responded that they would likely be in jail or no longer alive.

By using education to teach academics, life skills, and self-empowerment, the school is able to take the negative legal experiences of its students and develop a system of healing that emphasizes healthy, non-offending lifestyles. In doing so, the teachers focus on the future and essentially ignore the histories of their students, thereby circumventing labels such as "at risk", "young offender", or "high needs" and concentrating, rather, on what the students need to develop intellectually and socially. This policy of discarding labels is very much in accord with First Nations spirituality and healing which focuses on the elimination of guilt and blame from the healing process. At a very basic level, the concept of "at risk" is based on individual blame. 
Second, the school operates on the basis of a non-authoritarian consensus system: students decide on curriculum, marking, school social events, and discipline or justice issues which are imposed upon them in conventional systems. The rationale is that one of the basic problems for marginal youth (and all youth, more generally) is their disenfranchised position in the world. By investing their lives with basic human rights, the school teaches students that, despite the legal labels that have been placed on them, their role within the school is one of importance and credibility. As a result, retention rates are high; when students discussed their educational satisfaction, their main comments focused on their wish to stay at school 24 hours a day.

The basic problem for Won Ska School, despite its record of success with highly damaged students, is that it is constantly fighting for enough physical and financial resources to provide a comfortable school. Moreover, it is continually fighting for credibility. The school poses several problems for the local school board. It does not use a standard curriculum because the programs are students-driven. Furthermore, one-to-one learning/mentoring is expensive. The school, as well, rejects offender/risk designations for its students and does not engage in dialogue with the school board and the community regarding potentially dangerous students. Finally, it allows students to remain in school as long as they wish, some well into their 20 s, and this violates the traditional educational focus on high school as a place for adolescents only. Ironically, the things that make Won Ska highly successful are the same things that jeopardize its existence. Standardized, factory-like, fiscally efficient education unfortunately remains the norm in education, often to the detriment of students as unique individuals (Giroux, 2003b).

At the end of the day, however, by using community resource people as much as possible, Won Ska Cultural School provides the opportunity for adults to interact with troubled youth as real people, an important first step in neutralizing the stigma of their being a young offender.

\section{Education as a Vehicle for Holistic Healing - Cote First Nations}

It is remarkable in Aboriginal-based alternative schools how education and health are held as inseparable. Education, in such a philosophical context, is part of the process through which the personal, social, and physical environments are healed.

Several years ago, with several colleagues from the University of Saskatchewan, I had the good fortune to work with the Cote First Nation on the preliminary development of social and environmental proposals for the community. The Cote First Nation is a Saulteaux community located in southeastern Saskatchewan. The community is relatively small and, as is typical of many Aboriginal communities in western Canada, the land has been "mined" by non-Aboriginal farmers for decades. The absentee tenants have often left the land denuded and damaged and intensive agriculture has contaminated the land and the water. The Cote people were aware of this and began to work on a proposal to take back their land, in large part to improve their own levels of health. They envisioned a series of land use proposals that involved organic farming and reforestation. The other issue faced by the community was the loss of its children to urban areas. Cote is relatively isolated from any urban centre and, like many rural communities, had a difficult time providing adequate employment or social opportunities for its young people. As a consequence, the dropout rates from high school were quite high as were the rates of youth in trouble with the law. 
The community, in resolution of the social and physical problems they faced, proposed that a reformed education system could, in part, hold the answer. There is a new school on the reserve and the people proposed that the school become the centre of the healing project. The idea was that the school curriculum must reflect not only the formal academic needs of the students but also the community's ability to teach beyond formal education. The priority in this regard is that children and youth learn to be citizens of the earth, that they gain an appreciation for and an understanding of the earth as a living environment, and how this environment is the basis of their own physical and emotional well-being. Their proposal involved the use of the school day to teach formal requirements and the local environment to teach life skills. This time outside of formal school would entail working on environmental projects on the reserve, learning traditional knowledge and languages, designing and implementing new projects involving land restoration, and engaging in physical activities to improve levels of fitness amongst the students.

The initial project was a community garden on school property in which the children participated as growers. The Cote community was convinced that time on the land would instill in the children and youth an appreciation of the importance of food and how safe food can be grown without chemicals, a sense of how land and people are inevitably connected, and a sense of proprietorship over their own well-being. In this new and rather unique education paradigm, the teachers would be prepared to share the instruction duties with Elders from the reserve with the goal of providing students with both traditional and contemporary knowledge. The students would learn the "science" of horticulture but also the spirituality involved in the human affinity with the land. Furthermore, in their interactions with the Elders, the students would be exposed to their cultural history and immersed in the Anishnabe language. In a more general sense, what the interactions with Elders teach is a connectedness across generations, something that has been lost in conventional societies that ask people to disengage when they reach the age of 65 . Such a context also allows for older generations to learn from children and youth, a potential that is almost non-existent in the conventional industrial world.

The Cote proposal does not intend to turn back the clock. It does, however, advise that if students do not understand the past, if they cannot conceive of living on reserve in a relatively pastoral context, they will be lost to the Cote community. It also does not diminish the importance of formal education, for the Cote people see the value of reading, writing, arithmetic, and more. They do believe, however, in a rather revolutionary way, that you cannot bombard students exclusively with formal education without alienating them from the community. Their proposal then, was to fuse formal learning with traditional learning in an "on the land" context. For example, one of the initial projects, which would be connected to the school, was to involve the planting of shelter belts throughout the reserve to be maintained, in part, by the students. The traditional Cote people, more than seven decades ago, depended on trees for their livelihood. They produced maple syrup, berry crops and a sustainable lumber industry. The shelter belt proposal is intended to teach the environmental importance of tree planting, with the traditional uses of trees as part of a sustainable community, and further how healthy land is essential to healthy people.

The types of projects that have been envisioned and proposed by the Cote community, and are in the seminal stages of implementation, are essentially part of a new form of education that 
melds formal education with life skills mentoring based on a conception of health writ large. The fundamental goal of this system of learning is threefold: to provide the students with the academic and life skills to enable them to be happy and productive citizens; to create a context in which mutual learning takes place across generations (where mentoring is more important than lecturing); and, to create in the students an appreciation for the social and physical environment, especially as it relates their personal health. The Cote people believe that if education can produce these desired results, their children and youth will not be lost to the jeopardy of the urban world, and that if they decide to leave their community, they will have a holistic intelligence that will make them strong people and resilient to the health risks that they currently see in their youth, especially those who have migrated to the city. Their proposal, then, is to make education an intrinsic part of the everyday world in a cultural and spiritual milieu that focuses on a multi-dimensional understanding of healthy people and healthy communities.

\section{Conclusion}

The pressing question that emanates from the foregoing discussions is this: Why would powerful people and groups choose, either deliberately or inadvertently, to stigmatize and control young people, especially young people who live on the margins of the society? Part of the reasoning must be that as the adult world makes moral or judicial judgments about youth, they not only reinforce the notion that adults are productive and youth are not, but they also reinforce class, race, and gender ideologies that suggest that certain youth (e.g., visible minority and Aboriginal youth, poor children and youth, street kids) are less moral and redeemable than others.

Furthermore, we need to put our condemnation of children and youth in an historical context. With respect to the histories of Aboriginal children in residential schools and immigrant children in industrial Canada, Canadian society understood the delinquency and incorrigibility of young people as closely tied to the need for children and youth in the labour market, that the coerced or enforced employment of youth is often tied to the contemporary labour market need for cheap or free labour (Schissel \& Wotherspoon, 2003). Côté and Allahar (1994) argued several years ago that young people, in general, are disenfranchised and lacking power, rights, and legitimacy. At the same time, this demographic is crucial to the economic system because it constitutes a cheap source of labour, as well as a massive consumer market. Their sequel to this work (Côté \& Allahar, 2006) reinforces their original argument and illustrates that little has changed. Politically and economically speaking, then, those in control have to ensure that young people do not realize the extent to which they are crucial to the survival of the system, and that they do not band together and rebel against the system. To prevent this kind of uprising and maintain the status quo, dominant interests use ideology and subtle ideological control, as Schissel (2006) notes:

The general dispossession of youth is accompanied by popular discourse that demonizes kids as dangerous. . .individual and corporate business interests, through their control of the media, offer portraits of young people as potentially dangerous, violent, and morally bereft (Giroux, 2003a; Glassner, 1999; Schissel, 1997). If the general public views youth as dangerous and prone to criminality, it is less likely to be sympathetic to the increasingly dire economic situation that today's youth face. This economic situation is the direct result of cuts to social programs implemented 
by the federal government at the insistence of business groups who have successfully lobbied against welfare liberalism (see McBride, 2005; Carroll, 2004; Teeple, 2000; Burman, 1996). Further, in marginalizing youth, the state undercuts social programs that target youth in particular. The relationship between poverty levels and youth crime is rarely discussed in media representations of young criminals. Instead, media images are of youth who are lazy, unwilling to work, and criminally volatile. (p. 139)

Males (1996, 2000) argues, in addition, that the moral and judicial attack on children and youth stems in large part from the needs of the baby boom generation to protect its investments and its pensions. The logic here is that the disenfranchisement of younger generations, either through the labour market or the crime control system, facilitates the democratic dominance of the baby boom generation. Its money is protected through access to cheap labour, to youth consumerism, and through the minimization of social programs that sustain and foster the welfare of young generations. Such social programs put financial pressure on government resources that the boom generation thinks should be directed, by right of its contributions in taxes, to an increasingly large pension-eligible generation. This is a philosophy that forgets that the world does not necessarily or rightfully belong to an adult generation but is instead borrowed from a younger generation.

As we attempt to come to grips with the expanding state control of youth, we need to try to understand whether children and youth are perceived to be and are, in fact, an increasing reserve army of marginalized labour. Now, more than ever, youth are both in demand as consumers and as underpaid labourers. The multinational fast food industry is a typical example of global capitalism that flourishes on the backs of part-time, poorly paid child and youth labourers who receive no labour benefits, have no rights to collective action, and are often exposed to dangerous work. In fact, compared to adults, youth and child work in North America is considerably more dangerous than adult work (Schissel, 2001). The absolute denial of the rights of children and youth in the labour market coincides quite dramatically with the denial of the rights of children and youth to fair and impartial justice, a denial that is embedded in modern day youth justice policy in Canada.

As an antidote to conservative law and order politics, the importance of the kinds of social policies that emanate from research on crime prevention and alternatives to justice cannot be overstated. Saskatoon is typical of many Canadian cities which have tried to deal with issues such as child and youth prostitution through legal avenues. Unfortunately, successes have been few. When children and youth are sexually exploited and assaulted by pimps and adult pedophiles, the law's best purpose is not served through legal apparatus like the former Young Offenders Act or the new Youth Criminal Justice Act. In fact, when the police arrest children and youths for involvement in the sex trade, they are doubly jeopardizing kids.

Simply put, the law needs to change very fundamentally. The Youth Criminal Justice act does have progressive, caring dimensions that include provisions for diverting youth from the justice system into community-based, alternatives to a formal justice system which incarcerates. Unfortunately, the "security of the society" framework upon which the act is based could easily become more punitive and more comprehensive than previous incarnations of youth justice in Canada - or nothing could change - especially as neo-liberal societies adamantly oppose 
increased spending on social justice programs like alternative, community-based programs for young offenders.

I argue in my work that any attempt to change the justice system - for example, to include the legal system in the protection of children and youth - without the involvement of education and a profound understanding of health and marginality is futile. For example, safe houses are important but if they do not provide a context in which street kids can develop a sense of selfworth and competency, and where they can access services to become healthy and secure, they are only temporary places of refuge. Furthermore, if social policies are blind to the epidemic of ill health that characterizes marginalized children and youth - closely tied to issues of race, class, gender, and geography - they are doomed to failure. My research proposes that involvement with the law for children and youth is a profound individual and collective health risk, and that, as a result, the courts are not the places where youth justice can occur. Fundamental justice can arise, however, if we reframe the way that we think about institutions like education, if we constitute schools, for example, as democratic communities that care for the whole person. 


\section{References}

Bell, S. (2002a). Girls in trouble. In B. Schissel \& C. Brooks (Eds.), Marginality and condemnation: An introduction to critical criminology in Canada (pp. 129-152). Halifax, NS: Fernwood.

Bell, S. (2002b). Young offenders and juvenile justice: A century after the fact. Scarborough, ON: Thompson Nelson.

Burman, P. (1996). Poverty's bonds: Power and agency in the social relations of welfare. Toronto: Thompson Educational Publishing.

Carroll, W. (2004). Corporate power in a globalizing world: A study in elite social organization. Don Mills, ON: Oxford University Press.

Côté, J. E., \& Allahar, A. L. (1994). Generation on hold: Coming of age in the late twentieth century. Toronto: Stoddart

Côté, J. E., \& Allahar, A. L. (2006). Critical youth studies: A Canadian focus. Toronto: Pearson Prentice Hall.

Doob, A., \& Cesaroni, C. (2004). Responding to youth crime in Canada. Toronto: University of Toronto Press.

Faith, K. (1993). Unruly women: The politics of confinement and resistance. Vancouver, BC: Press Gang Publishers.

Giroux, H. (2003a). The abandoned generation: Democracy beyond the culture of fear. New York: Palgrave MacMillan.

Giroux, H. (2003b). Public time and educated hope: Educational leadership and the war against youth. The Initiative Anthology. www.muohio.edu/InitiativeAnthology/.

Glassner, B. (1999). The culture of fear: Why Americans are afraid of the wrong things. New York: Basic Books.

Green, R. G., \& Healy, K. (2003). Tough on kids: Rethinking approaches to youth justice. Saskatoon, SK: Purich Publishing.

Hamilton, A. C., \& Sinclair, C. M (1991). The justice system and Aboriginal people. Report of the Aboriginal Justice Inquiry of Manitota (Chapter VI). Winnipeg, MB: Queen’s Printer.

Henry, F., Tator, C., Mattis, W., \& Rees, T. (2000). The colour of democracy: Racism in Canadian society (2nd ed.). Toronto: Harcourt Brace and Company. 
Hogeveen, B., \& Smandych, R. (2001). Origins of the newly proposed Canadian Youth Criminal Justice Act: Political discourse and the perceived crisis in youth crime in the 1990s. In R. Smandych (Ed.), Youth justice: History, legislation and reform (pp. 144-169). Toronto: Harcourt Brace.

Males, M. (1996). Scapegoat generation: America's war on adolescents. Monroe, ME: Common Courage Press.

Males, M. (2000). Framing youth: 10 myths about the next generation. Monroe, ME: Common Courage Press.

Mallea, P. (1999). Getting tough on kids: Young offenders and the "law and order" agenda. Ottawa: Canadian Centre for Policy Alternatives.

McBride, S. (2005). Paradigm shift: Globalization and the Canadian state. Halifax, NS: Fernwood.

Newfoundland. (2001). Youth justice: A community response [PLIAN 2(4) March]. St. John’s: Public Legal Information Association of Newfoundland.

Royal Commission on Aboriginal Peoples (RCAP). (1996). Bridging the cultural divide. Ottawa: Ministry of Supply and Services.

Saskatchewan Justice. (2004). Saskatchewan commission on First Nations and Metis people and justice reform. Regina: Government of Saskatchewan.

Schiraldi, V., \& Zeidenberg, J. (1997). The risks juveniles face when they are incarcerated with adults. Washington, DC: The Justice Policy Institute.

Schissel, B. (1993). The social dimensions of Canadian youth justice. Don Mills, ON: Oxford University Press.

Schissel, B. (1997). Youth crime, moral panics, and the politics of hate. Halifax, NS: Fernwood Publishing.

Schissel, B. (2001). The pathology of powerlessness: Adolescent health in Canada. In B. S. Bolaria \& H. Dickinson (Eds.), Health, illness, and health care in Canada (Chapter 16). Toronto: Harcourt Brace and Company, Canada.

Schissel, B. (2002). Youth crime, youth justice and the politics of marginalization. In B. Schissel \& C. Brooks (Eds.), Marginality and condemnation: An introduction to critical criminology in Canada (pp. 109-127). Halifax, NS: Fernwood.

Schissel, B. (2006). Still blaming children: Youth conduct and the politics of child hating. Halifax, NS: Fernwood.

Schissel, B., \& Fedec, K. (1999). The selling of innocence: The gestalt of danger in the lives of youth prostitutes. Canadian Journal of Criminology, 41(1), 33-56. 
Schissel, B., \& Wotherspoon, T. (2003). Education, oppression and emancipation: The legacy of school for Aboriginal people. Don Mills, ON: Oxford University Press.

Shaw, M. (2000). Women, violence and disorder in prisons. In K. Hannah-Moffat \& M. Shaw (Eds.), An ideal prison? Critical essays on women's imprisonment in Canada (pp. 61-70). Halifax, NS: Fernwood.

Teeple, G. (2000). Globalization and the decline of social welfare into the 21st century. Aurora, ON: Garamond.

York, G. (1992). The dispossessed: Life and death in Native Canada. Toronto: Little, Brown and Company. 